\title{
Relativisation in Dutch diaries, private letters and newspapers (1770-1840)
}

\section{A genre-specific national language?}

\author{
Andreas Krogull, Rutten Gijsbert \& Marijke van der Wal \\ Leiden University
}

The paper focuses on three important themes in historical sociolinguistics: (1) the emergence of national language planning in the Netherlands around 1800,

(2) the influence of historical prescriptivism on usage, and (3) genre as a crucial factor in explaining variation and change. The case study deals with relativisation, particularly the neuter relative pronoun in eighteenth- and nineteenth-century Dutch. Analysing both internal and external factors, we show that the definiteness of the antecedent does not explain the variation, contrary to what is assumed in the research literature. Likewise, a strong effect of language norms on usage patterns cannot be established. The crucial factor turns out to be genre.

Keywords: relativisation; relative clause; Dutch; Germanic; historical sociolinguistics; nationalism; language planning; genre variation

\section{Introduction}

This paper focuses on three important themes in historical sociolinguistics. First, we explore the relationship between sociopolitical changes such as the rise of nationalism around 1800 on the one hand, and language as a social phenomenon on the other hand. Second, we address the issue of the influence of language norms on usage patterns in historical contexts. Third, we focus on genre as a crucial factor in explaining variation and change.

The case study that we address is relativisation in the history of Dutch, particularly the genre-dependent use of neuter relative pronouns in eighteenth- and nineteenth-century Dutch - a period of intense nation-building and linguistic nationalism. Thus, we present the first corpus-based study of the neuter relative pronoun in historical Dutch. Analysing both internal and external factors, we show that the definiteness of the antecedent does not explain the variation, contrary to what 
is assumed in the research literature. Likewise, a strong effect of language norms on usage patterns cannot be established. The crucial factor turns out to be genre.

In Section 2, we sketch the historical-sociolinguistic background of our study. Section 3 first discusses patterns of relativisation in the Germanic languages before zooming in on Dutch (Section 3.1). Then, we focus on Dutch relative pronouns (3.2), and in particular on variation and change in the neuter pronoun (3.3). After having established the main variants of our study, we discuss norms for relativisation that can be found in the eighteenth- and early nineteenth-century metalinguistic tradition (3.4). In Section 4, we explain our methodology. In Section 5, we present the results, which we discuss in the concluding Section 6.

\section{Historical-sociolinguistic background}

The eighteenth and nineteenth centuries are highly interesting from a sociolinguistic perspective. Within the Going Dutch project, ${ }^{1}$ we study the rise of standard language ideology in the northern Low Countries in the second half of the eighteenth century, its implementation through language planning and educational policy at the beginning of the nineteenth century, and possible effects of planning on language use. The northern Low Countries roughly correspond to the presentday Netherlands. In this area, the second half of the eighteenth century was characterised by a strong nationalist discourse, in which the written variety of Dutch was increasingly conceptualised as a symbol of the unity of the Dutch nation (Rutten 2016a). Around 1800, the discursive nationalisation of language was part of a wider cultural-nationalist discourse that developed in tandem with the formation of the modern Dutch nation-state. As elsewhere in Europe, the call could be heard for a homogeneous language that would iconically represent the nation.

In the northern Low Countries, this call was put into political practice almost immediately. After a few rounds of consultation with well-known language experts, the Dutch government endorsed and financed the publication of national spelling and grammar guidelines (Siegenbeek 1804, Weiland 1805). These officialised rules of 'the' Dutch language, laid down in the so-called schrijftaalregeling (written language regulation), were also integrated into the new language-in-education policy. The 'national' language was intended to be used in the administrative and educational domains. One of the tasks of the newly founded national school inspection system was to surveil the implementation of the national language in schools.

1. Project 'Going Dutch. The Construction of Dutch in Policy, Practice and Discourse, 17501850', supported by a VIDI grant from the Netherlands Organisation for Scientific Research (NWO), awarded to Gijsbert Rutten. 
Up to the present day, hardly anything is known about the effectiveness of this national language policy on language use, and more generally about the influence of this policy on patterns of variation and change. While the more general topic of the interplay of normativity, prescription and language use has attracted quite some attention recently (e.g. Rutten, Vosters \& Vandenbussche 2014, Anderwald 2016), there is hardly any research into the success of concrete language policy measures in historical contexts (Langer 2011). In this study, we analyse variation and change in Dutch relativisation patterns, taking into account the possible normative influence of the national language regulations.

\section{The variable}

\subsection{Changes in relativisation}

The Germanic relativisation systems have been in heavy flux throughout the centuries (van der Wal 2002). There are many different relativisation strategies in the Germanic languages, which can moreover vary from period to period. Relative particles occur in Gothic, viz. as the invariable suffix -ei (Braune 1981:102), and have also been attested in older stages of Dutch, German, Frisian and English as well as in Old Norse (van der Horst 2008: 176-177). Today, the invariable particle som occurs in Norwegian, Swedish and Danish (Askedal 1994:234, Andersson 1994:282, Haberland 1994:345-346), while Icelandic has sem (Thráinsson 1994:157) and Faroese sum (Barnes \& Weyhe 1994:203). These languages often also have other particles and/or grammaticalised pronouns (e.g. Andersson 1994:282).

Extensive systems of relative pronouns exist in Dutch, German and English. In general, these are grammaticalised forms of the demonstrative and interrogative pronouns. English also uses invariable that, which still "stood practically alone as a relativiser" (Fischer 1992:296) in the thirteenth century. Later on, originally interrogative wh-forms such as who, what and which became more frequently used, thus replacing the demonstrative pronouns that had been in use in relative positions as well (cf. Romaine 2009 [1982]: 64). Standard German has a system of relative pronouns (der, die, das) derived from the demonstrative pronoun and equally sensitive to gender and case marking. The online Atlas zur deutschen Alltagssprache shows that in present-day colloquial German, die occurs along with die wo and wo in feminine object position. ${ }^{2}$ The invariable particle wo mainly occurs in the southwest (Baden-Württemberg, Switzerland).

2. See AdA, map of 'relat. "wo", "die”, “die wo"” (http://www.atlas-alltagssprache.de/runde-7/ $\mathrm{f} 12 \mathrm{c} /)$. 
In addition to the various particles, often derived from conjunctions, and the many pronominal forms, relative adverbs exist in locative expressions and metaphorical extensions thereof. For example, Old and Middle English had predominantly there, which was gradually replaced by where (Fischer 1992:304, Rissanen 1999:301). A similar change has taken place in Dutch, viz. from daar to waar (Rutten \& van der Wal 2014: Chapter 8). Moreover, this change also affects so-called relative pronominal adverbs, consisting of a relative adverb and a preposition, for example Dutch daarin 'therein' > waarin 'wherein'.

Apart from particles, pronouns, adverbs and pronominal adverbs, many Germanic languages also allow combinations of these, such as the aforementioned die wo in colloquial Southern German, there that in Early Modern English (Rissanen 1999:301), or die dat 'who that' in some present-day dialects of Dutch (SAND 2005: Map 84b). Finally, a zero constituent is a possible relativisation strategy, particularly in English (cf. Hinrichs et al. 2015).

The inherent variability of relativisation strategies renders them interesting topics for historical sociolinguists; see for example, Romaine (2009 [1982]), Bergs (2005: Chapter 5) and Nevalainen \& Raumolin-Brunberg (2003) for English, and Negele (2012) for German. In the case of Dutch, the most extensive historical sociolinguistic analyses are reported in Rutten \& van der Wal (2014: Chapter 8), who focus on the change from $d$ - to $w$-forms in the case of relative adverbs and relative pronominal adverbs.

The change from $d$ - to $w$-forms, that is, from originally demonstrative to originally interrogative forms appears to be a very broad West Germanic development. ${ }^{3}$ In Dutch, it affects both pronominal and adverbial relativisers, and occurs both in restrictive and non-restrictive relative clauses, as well as in dependent and free (independent, headless) relative clauses (de Schutter \& Kloots 2000). In the case of relative adverbs and relative pronominal adverbs, $d$-forms such as thar and daer 'there' dominate the oldest written Dutch, though waer 'where' can already be found in the thirteenth century (van der Horst 2008: 476-477). The major change took place much later, however, in the seventeenth and eighteenth centuries (Rutten \& van der Wal 2014:289-293, cf. van der Horst \& Storm 1991:109-111), though daar and daar+preposition can still be found in nineteenth-century Dutch (van der Horst 2008: 1868, 1899-1900). In present-day dialects, locative expressions mostly attract $w$-relativisers, i.e. variants of Standard Dutch waar 'where'. Relative clauses with a $d$-form are restricted to specific areas, mainly Friesland in the north and North Brabant in the middle of the language area, and even there

3. Hinrichs et al. (2015), however, show that in modern Standard English restrictive relative clauses that is replacing which. 
most localities have the $w$-form as well as the $d$-form (SAND 2005:Map 88b). In other words, the change from $d$ - to $w$-forms is more or less complete in the case of adverbs and pronominal adverbs.

\subsection{Focusing on Dutch relative pronouns}

Given the many types of relativisers and the complexity of forms, we decided to focus on relative pronouns for the purpose of this paper. Table 1 shows the nominative forms of the main variants in the singular.

Table 1. Relative pronoun nominative singular (main variants, normalised spelling)

\begin{tabular}{lll}
\hline & Masc. and fem. sing & Neuter sing \\
\hline $\begin{array}{l}\text { Old Dutch } \\
\text { before } 1150\end{array}$ & die & dat \\
$\begin{array}{l}\text { Middle Dutch } \\
1150-1500\end{array}$ & die / wie / welke / dewelke & dat / wat / welk / hetwelk \\
$\begin{array}{l}\text { Modern Dutch } \\
1500 \text {-present }\end{array}$ & die / wie / welke / dewelke & dat / wat / welk / hetwelk / hetgeen \\
\hline
\end{tabular}

Historically, Dutch relative pronouns derive from the demonstrative pronoun. In the Old and Middle Dutch period, die is found for masculine and feminine referents, and dat for neuter referents (van der Horst 2008: 172-173,377). These are declined for case, giving diens in the masculine and neuter genitive singular, dier in the genitive plural and in the feminine genitive and dative singular, and dien in the dative plural, in the masculine and neuter dative singular, as well as in the masculine accusative singular. In present-day Standard Dutch, which has a common and a neuter gender and hardly any case marking, die is still the common gender and plural form, and dat the neuter singular form. However, wie and wat have largely replaced die and dat in specific contexts such as free relatives. This development began already in late Middle Dutch (van der Horst 2008: 603). Today, $d$-forms still occur in many dialects, often next to $w$-forms (SAND 2005: Map 90b; see also below).

In the neuter singular object and subject position, wat is currently replacing dat (cf. van der Horst 2008: 1683). Still relatively rare is wie in the common gender subject/object position, though examples are easily found (van der Horst 2008: 1683). In present-day dialects, variants of die and wie as well as the particle dat occur in masculine subject and object positions (SAND 2005: Maps 82a and 82b). In the historical genitive, originally interrogative forms have been used since the Middle Dutch period, viz. wiens 'whose' in the masculine and neuter singular, and wier in the feminine singular and in the plural (cf. van der Horst 2008: 602). 
These are still used today, though they are often considered to be formal and/or restricted to writing (ANS: Sections 5.8.6). However, in dialects, both diens and wiens are quite common (SAND 2005: Map 89b). In sum, the change from $d$ - to $w$-forms has progressed far less in the case of pronouns than in the case of relative and relative pronominal adverbs.

Furthermore, additional pronominal forms with an interrogative origin already came into use in the Middle Dutch period, viz. welc or welk 'which' and variants thereof, both spelling variants and forms declined for case such as welker in the genitive plural, and welkes in the masculine genitive singular (van der Horst 2008:380). ${ }^{4}$ In present-day dialects of Dutch, variants of welk are not reported according to SAND (2005: Maps 82, 83, 85, 86, 89).

Moreover, the extended forms dewelke 'the which' for masculine and feminine referents, and hetwelk 'the which' for neuter referents also already occur in the Middle Dutch period. ${ }^{5}$ Van der Horst (2008: 830) suggests that dewelke and hetwelk were particularly popular in the sixteenth and seventeenth centuries. In English, a similar competition between which and the which was decided in favour of which by the sixteenth century (Nevalainen \& Raumolin-Brunberg 2003:73-74).

Another neuter form, usually dated to the sixteenth century though a few older attestations exist, is hetgeen 'lit. the yonder' (Schoonenboom 1997, van der Horst 2008:607, 831). It probably developed from the demonstrative hetgeen plus the relative particle or subordinating conjunction dat 'that'. The expression hetgeen dat 'which, that which', often used in free relatives, subsequently eroded to hetgeen and took on the function of a neuter relative pronoun, synonymous with the already existing forms dat, wat, welk and hetwelk. Schoonenboom (1997) shows how in Bible translations from the fourteenth to the twentieth century hetgeen is first absent, then becomes an important variant in the seventeenth to nineteenth centuries, declining again in the twentieth century.

The inventory of pronominal relativisers is substantial, so we decided to focus on the neuter relative pronoun in the singular. This choice was arbitrary, and we are looking forward to discussing the masculine and feminine forms elsewhere. Furthermore, we focus on the neuter relative pronoun in subject and object posi-

4. As in the case of German welch, these are sometimes considered Latinisms or Gallicisms (van der Horst 2008:380). Likewise, the rise of wh-forms in Middle English is sometimes attributed to contact with French and/or Latin, although it is also argued that the contact situation merely strengthened an already existing trend (Fischer 1992:299, Rissanen 1999:295).

5. Here, too, the influence of Latin and/or French, in particular of forms such as lequel, has been suggested (van der Horst 2008:381). 
tion only. The reason for this is that in other positions, and particularly in combination with prepositions, the pronominal paradigm takes over the forms of the pronominal adverbial paradigm. ${ }^{6}$ This paradigmatic mixture of the pronominal and the adverbial forms has led us to limiting our investigation to (bare) subject and object positions. The presence of pronominal adverbs would imply addressing the related, but equally substantial topic of the change from $d$ - to $w$-forms in relative adverbs and in relative pronominal adverbs.

\subsection{The neuter relative pronoun in Late Modern Dutch}

From the research literature on Dutch neuter relative pronouns in subject and object position, the following set of possible variants can be inferred: dat, wat, hetgeen, welk, hetwelk. These are also the variants that occur in our corpus. The corpus will be introduced in Section 4. Here, we give corpus examples of each of the available forms (1-5).

(1) het beelderige mooye mandje dat zy voor my gemaakt heeft the lovely beautiful basket that she for me made has 'the lovely beautiful basket that she has made for me'

(2) Ons rytuig wat wy om 8 Uur besteld hadden our coach what we at eight o'clock ordered had 'our coach that we had ordered at eight o'clock'

(3) het gure en regenachtig weder, het geen reeds den geheelen the biting and rainy weather the-yonder already the whole dag had geduurd day had lasted

'the biting and rainy weather which had already lasted thewhole day'

(4) het geheim welk 'er gaande was the secret which there happening was 'the secret that was happening there'

6. In present-day Standard Dutch, this is optional with animate referents, and obligatory with inanimate referents, e.g. het kind met wie / waarmee ik speel'the child with whom / wherewith I play'. Prescriptivists tend to reject waarmee, arguing that the pronominal form is for animate referents and the adverbial for inanimate referents. Compare het toetsenbord waarmee (/? met wat) ik schrijf 'the keyboard where-with (/? with what) I write.' Here, the adverbial form waarmee is preferred to the pronominal option met wat, which is in fact unusual in Standard Dutch, perhaps even impossible. 
(5) het schoon gezicht 't welk men nog lang van deze zyde op the beautiful view the which one still long from this side of de stad' blyft genieten the city remains enjoying 'the beautiful view that one keeps enjoying from this side of the city for a long time'

Changes in Dutch relativisation have been discussed from various perspectives. An early generalisation claims that the rise of $w$-forms depends on the definiteness of the antecedent (van der Horst 1988: 196, cf. van der Wal 2002). In a modified and/or weakened form, the claim also occurs in Schoonenboom (2000) and de Schutter \& Kloots (2000). The generalisation locates types of antecedent on a cline from indefinite to definite (6). The first and most indefinite context (I) is that of free or headless relatives, i.e. which lack an antecedent altogether.

(6) (I) free relatives $>$ (II) clause or sentence $>$ (III) indefinite pronoun $>$ (IV) nominalised adjectives $>(\mathrm{V})$ indefinite noun phrase $>(\mathrm{VI})$ definite noun phrase

According to van der Horst (1988), $w$-forms entered the language from left to right, i.e. from indefinite to definite contexts. Rutten (2010) and Rutten \& van der Wal (2014: Chapter 8) offer counter examples and argue for a different approach, taking into account sociolinguistic factors and constructional diffusion, i.e. a spread of $w$-forms from one form-meaning pairing to another. Those studies primarily focused on the relative and relative pronominal adverbs. For relative pronouns in Late Modern Dutch, however, much less research literature is available, and, as far as we know, the present study is the first corpus-based study of neuter relative pronouns. This means that the generalisation in (6) has never been tested on corpus data, which is why we will incorporate the definiteness cline (6) into our case study.

Genre or register effects have been claimed to influence the rise of $w h$-forms in English. Fischer (1992:301), following Romaine 2009 [1982], maintains whforms entered Middle English via the most complex styles of writing. Rissanen (1999: 295) calls it a change from above from the formal and literary levels. Rutten $\&$ van der Wal (2014:297-302) show that $w$-forms spread from above in social terms in the case of relative and relative pronominal adverbs.

Fischer (1992:297, 300) argues that wh-forms in Middle English occurred earlier in non-restrictive than in restrictive relative clauses. Rissanen (1999:293,295-296) claims that continuative relative clauses, in particular, promoted wh-forms. Rutten \& van der Wal (2014:317), discussing adverbial relatives, show that non-restrictive clauses, i.e. appositives, are indeed progressive in seventeenth- and eighteenth-century Dutch, but only in final position. Thus, the 
syntactic position is important: when embedded, restrictive and appositive relative clauses behave similarly. In a follow-up study, Rutten \& van der Wal (2017) argue that within the category of final appositives, continuative relative clauses constitute the only progressive context. Other types of final appositives pattern similarly to final restrictive clauses. We therefore assume that the type of relative clause is not essential in Dutch, with the exception of continuative appositives. Since these are continuations of the discourse at a non-local level, introducing new information and referring back to the previous discourse only globally, they are included in (6) under the category of clausal or sentential antecedents.

\subsection{Norms for relativisation in Late Modern Dutch}

In the eighteenth-century normative tradition, relativisation does not appear to be a core topic (van der Wal 2003). In grammars, a variable number of relative pronouns are listed ranging from only wie, welk to die, dat, wie, welk(e), to which hetgeen and dewelke/hetwelke can be added. ${ }^{7}$ Sometimes relative pronominal adverbs are also taken into account, for instance in ten Kate's elaborate treatise (1723, I: 489). Apart from paradigms, specific rules for the use of relativisers are often lacking.

One of the few rules prescribed concerns the use of relative pronominal adverbs such as waarmee/daarmee 'where-with/there-with, with which'. Starting from Huydecoper (1730:469) and continuing to present-day prescriptivists, most grammarians argue that the use of relative pronominal adverbs should be restricted to inanimate referents (Section 3.2 and Footnote 6). An illustrative quotation in this respect is de Haes (1764:169): "Waer mede mag men wel op een werktuig, doch op geen persoon laten volgen; des moet men schryven, dien man, met wien ik ging; het mes waer mede ik sneed", that is, 'where with may follow a tool, not a person; consequently, one has to write that man, with whom I went; the knife where with I cut' (cf. also Tollius 1776: 95). Ten Kate (1723, I: 492) is an eighteenthcentury exception when defending the view that relative pronominal adverbs may refer to both animate and inanimate antecedents.

The author's choice between either the $w$ - or the $d$-variants remains unclear. For stylistic reasons, Huydecoper (1730:469) prefers the unsplit $w$-variant waerom 'where-for' to the split $d$-variant daer...om 'there...for'. Another rule regards the

7. Only wie, welk in Sewel $(1708: 121 ; 1712: 236)$, only die, dat, wie, wiens, wier in Kunst wordt door arbeid verkregen (1770:140). Die, dat, wie, welke occur in Moonen (1706:125,131), Elzevier (1761:64,69,71), van der Palm (1769-II:46,49-50). These four relativisers plus hetgeen in Tollius (1776:70), plus dewelke in Rudimenta (1802:27), plus both hetgeen and dewelke in Stijl \& van Bolhuis (1776:97) and van Bolhuis (1792:51). 
use of neuter relative hetgeen 'the-yonder' which is argued to be acceptable only as a free relative. Verwer (1707:50a) rejects instances of hetgene with a noun as antecedent as does Huydecoper (1730:620) who prescribes dat 'that' or 't welk' the which' instead of 't geen 'the-yonder' as relativisers with the nominal antecedent het werk 'the work'. Tollius (1776:74-75) also considers ' $t$ geen with a neuter noun as antecedent to be less acceptable. Ten Kate, however, is more lenient, as hetgeen is listed as an option alongside dat and hetwelke in his paradigms (1723, I, 489-491).

Ten Kate distinguishes three registers of language in his description of linguistic phenomena, which he terms styles (1723: I, 334; van der Wal 2002b: 56-59), viz. the sublime style (hoogdravend or verheven), the solemn style (deftig or statig) and the plain style (gemeenzaam). However, there are no clear correspondences between particular relativisers and these registers. In ten Kate's paradigms, most relativisers appear as options in all three registers, although hetwelke/dewelke belongs mainly, though not exclusively, to the sublime and solemn styles. For the neuter relative pronoun, we notice that hetgeen is represented in all three registers, contrary to wat 'what', which is fully absent. The register differences appear to imply mainly different degrees of case marking rather than exclusive relativisers: the higher the register, the more case endings we find.

In the final decade of the eighteenth century, van Bolhuis (1792:51-52) distinguishes current and less current relative pronouns. In his view, die, welke, de welke and oblique wie and wat are frequently used relativisers, whereas wie, wat, het [sic], hetgeen, and oblique die are less current. From that distinction, we may conclude that the $d$-relativisers diens, dien were giving way to the $w$-relativisers wiens, wien and that for some reason wie, wat and hetgeen in subject and object position were less frequent options. Seventy years earlier, ten Kate $(1723, \mathrm{I}, 489)$ had pointed out that, contrary to Latin, Dutch has more than one single relativiser that could be used for stylistic purposes. However, neither ten Kate's volume nor the other grammars and treatises belonging to the eighteenth-century normative tradition offered much guidance in this respect. Did this situation change when Weiland's national grammar was published in 1805 (see Section 2)?

What strikes us, first of all, is the relatively elaborate information on relativisation in Weiland (1805): not just a definition and paradigms, but also explicit rules for usage, observations on register differences and examples from which norms or rules can be inferred. Weiland's definition of relative pronouns comprises welke, dewelke, die and wie (1805: 119-120), although more relativisers are presented in his subsequent description and examples. ${ }^{8}$ From Weiland's (1805: 120-121) examples wien ik

8. Weiland (1799:123) presents the same list of relativisers with the addition of the neuter forms: welke, welk, dewelke, hetwelk, die, dat, wie, wat. 
mijn woord geef'to whom I give my word' and wat mij gebeurd is 'what happened to me', we conclude that in his view only $w$-forms can function as free relatives.

The neuter relativisers dat and hetwelk appear in the case of a sentence or clause as antecedent such as in zij spraken over deugd en godsvrucht, dat mij zeer aangenaam was 'they talked about virtue and piety, that was rather pleasant to me', as well as in Die zaak heeft eenen slechten keer genomen, het welk ik wel gevreesd had 'that matter turned out wrong, the which I had feared' (Weiland 1805:244). This relativisation choice raises the question about Weiland's attitude towards wat, hetgeen and welk. Weiland does not take a stand in his 1805 grammar, although previously he considered the free relative example hetgene $i k$ zeg, is waarheid' theyonder I say, is the truth' as legitimised in usage (Weiland 1799: 124).

The neuter form wat occurs in the indefinite pronoun combination alles wat 'all what', which is illustrated by examples such as alles, wat van hem gezegd wordt, is waar 'all that is said about him, is true' (Weiland 1805:121). A nominalised adjective such as het goede 'the goodness' as antecedent may occur with wat, but dat or hetwelk, welk are preferable (Weiland 1805:246). In the case of a noun phrase, either definite or indefinite, however, dat, hetwelk, welk are the only options as illustrated by the comment never "wat" added to the example het huis dat, of het welk gij gekocht hebt 'the house that, or the which you bought' (Weiland 1805:246).

Weiland (1805:120) also explicitly formulates a rule for the use of wiens and welks, both of which were often used indiscriminately for the neuter. According to Weiland, however, wiens is the appropriate genitive singular masculine form such as de man, wiens geleerdheid 'the man, whose erudition', and welks is the genitive singular neuter form such as het land, welks uitgestrektheid 'the land, which expanse. Ten years earlier, van Bolhuis (1792:51) had only presented examples from which the best usage of these relativisers could be inferred.

Furthermore, Weiland (1805:245) explains the case-dependent use of die, wie, welk after personal pronouns: die in the nominative case, and welke or wie in the other cases and in combination with prepositions. The choice between wie and welke is clarified by arguing that wie is usual in the genitive and dative masculine singular and after prepositions. ${ }^{9}$

Weiland (1805:246) also adopts the rule that restricts the use of relative pronominal adverbs to inanimate antecedents. Moreover, he explicitly characterises relative pronominal adverbs with animate antecedents as bad ( $k$ walijk) or incor-

9. Cf. Weiland (1805:246): hij was de man, wiens vriend ik wilde wezen 'he was the man, whose friend I wanted to be', wien ik zoo veel verschuldigd was 'to whom I owed so much', van wien ik zoo veel goeds ontvangen had 'from whom I had received so much goodness'. 
rect usage, both in spoken and written language. By allowing some freedom to deviate from this rule in literary language, he shows an awareness of register differences. The same awareness becomes clear when he claims that the relativisers welke and dewelke are mostly used in the so-called solemn style, whereas die is mostly used in the plain style. ${ }^{10}$ Previously, he had noted that dewelke was a less frequently used variant (Weiland 1805: 121).

Having examined various grammars and linguistic treatises, we have to conclude that little evidence for prescriptive rules on the choice between $d$ - and $w$-relativisers is to be found before 1800. In Weiland (1805), we find more detailed norms and rules than in his predecessors' publications. At the same time, he also agrees with the few existing rules on the use of relative pronominal adverbs and, according to Weiland (1799), with hetgeen being restricted to free relatives. The metalinguistic data available, however, still offer a limited view on the actual use of relativisers. Our corpus research will present evidence of relativisation strategies in actual language use before and after Weiland (1805).

\section{Methodology}

In order to investigate the interplay of language planning and patterns of variation and change, we compiled a multi-genre corpus of eighteenth- and nineteenth-century Dutch. The Going Dutch Corpus (cf. Footnote 1) comprises 421,878 words. It consists of two diachronic cross-sections, viz. period 1 (1770-1790) and period 2 (1820-1840), representing the generations before and after the national language policy was introduced in the early 1800 s.

Based on the assumption that diachronic changes have different effects on different genres, the Going Dutch Corpus comprises data from three genres: (1) private letters, (2) diaries and travelogues, and (3) newspapers. In line with current approaches to language histories 'from below', we included two types of handwritten ego-documents. First, private letters are considered as "the 'next best thing' to authentic spoken language" (Nevalainen \& Raumolin-Brunberg 2012:32) and have therefore become the prime sources used in historical-sociolinguistic research, see e.g. Nevalainen \& Raumolin-Brunberg (2003) for English, Elspaß (2005) for German, and Rutten \& van der Wal (2014), from which the eighteenth-century pri-

10. The following examples illustrate these differences: de gelukzaligheid des tegenwoordigen en toekomenden levens, welke langs verschillende wegen gezocht wordt 'the bliss of the present and future life which is sought in various ways', as opposed to hij woont in het huis, dat zijn vader gebouwd heeft 'he lives in the house, that his father built' (Weiland 1805:244). 
vate letters in the Going Dutch Corpus were partly taken. Secondly, we included diaries and travelogues ${ }^{11}$ as an additional type of ego-document. Third, the corpus also comprises newspapers, which represent published and edited language. This particular corpus design allows us to compare manuscript and print language in the context of top-down language planning. All texts in the Going Dutch Corpus, both handwritten and printed, were manually transcribed from digital images of original archive sources.

From a historical perspective, space is another crucial external factor. Therefore, we considered two geographical distinctions, i.e. variation across several regions as well as across the centre and the periphery. The Going Dutch Corpus

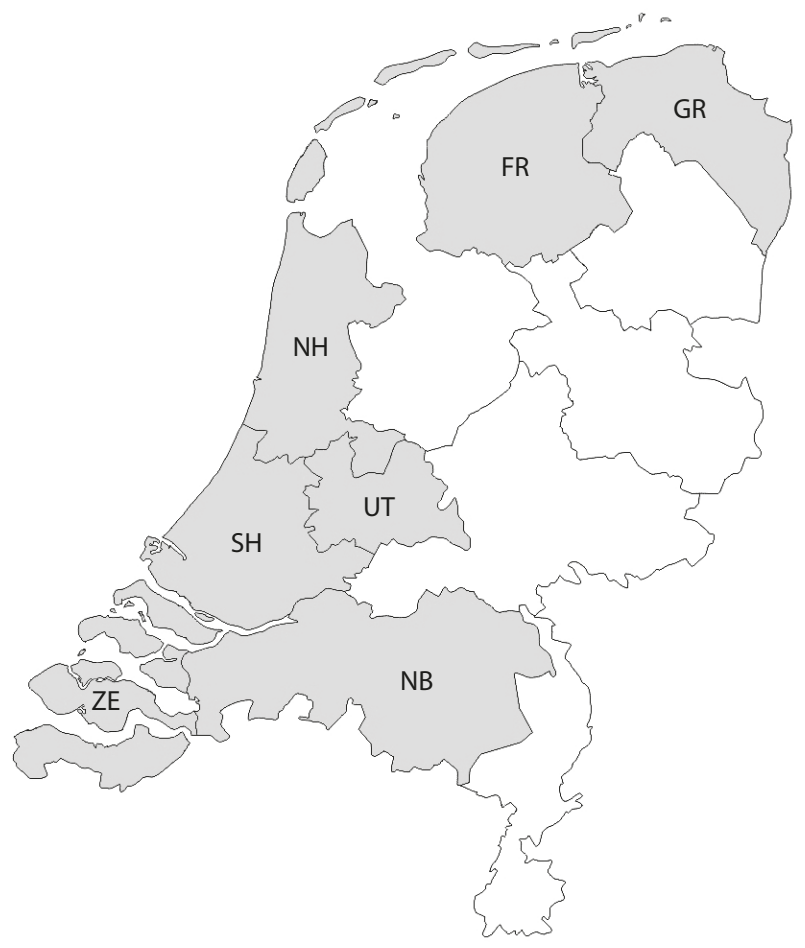

Figure 1. Map of the northern Netherlands indicating the regions represented in the corpus $(\mathrm{FR}=$ Friesland, $\mathrm{GR}=$ Groningen, $\mathrm{NB}=$ North Brabant, $\mathrm{NH}=$ North Holland, $\mathrm{SH}=$ South Holland, UT $=$ Utrecht, ZE $=$ Zeeland)

11. The genre referred to here as diaries and travelogues covers monologic ego-documents concerning mainly personal matters, either written in domestic or travel settings. In fact, the boundaries between the different (sub)types can be vague. A diary, for instance, can blend into a travelogue and vice versa (Lindeman et al. 1994:10). Texts primarily concerning administrative or business matters (e.g. account books or ship's logbooks) were excluded. 
covers seven regions of the northern Low Countries: North Holland, South Holland and Utrecht (which make up the centre of the investigated language area), Friesland, Groningen and North Brabant (considered as peripheral regions), as well as Zeeland. ${ }^{12}$ See Figure 1 for a map.

Finally, we incorporated gender as a social variable, which can be applied to the ego-documents. Although male writers are overrepresented (66\% in the entire corpus), we argue that one-third of these sources being written by women is still a considerable change compared to the near-absence of female writers in traditional language histories. In terms of socio-economic groups, most ego-documents in our corpus were written by members of the middle to the upper ranks of society, excluding the very highest rank. ${ }^{13}$

In sum, the Going Dutch Corpus covers two periods, three genres, seven regions, and in the case of ego-documents two genders. The ego-documents comprise 400 private letters written by 298 individuals, and 50 diaries and travelogues written by 50 individuals. Table 2 shows the make-up of the corpus.

For our analysis of Dutch neuter relative pronouns, we manually extracted the occurrences of the five variants: dat, wat, hetgeen, welk and hetwelk, also taking into account possible spelling variation. In the case of hetwelk, for instance, the pronoun might also occur as het welk, het welke, 't welk or twelk.

All non-relative occurrences were filtered out by hand, particularly tokens of dat (e.g. functioning as a subordinating conjunction or demonstrative pronoun) and wat (e.g. as an indefinite pronoun meaning 'something' or in the construction wat $x$ betreft 'as regards $x$ '). As discussed by Schoonenboom (2000:91-108) and Rutten (2010:8-9), the distinction between the relative and the interrogative interpretation of wat is not always clear-cut and thus difficult to keep apart (see also Fischer 1992:297-298 for the English case). We decided to remove all unambiguous instances of interrogative wat, but did include those cases in which both relative and interrogative interpretations are theoretically possible.

In total, we extracted more than a thousand tokens of Dutch neuter relative pronouns in subject and object position. The analysis will be presented and discussed in Section 5.

12. Historically, Zeeland was also part of the centre, particularly in the seventeenth century. However, Kloek \& Mijnhardt (2004:49) point out that this centre-periphery balance was shifting in subsequent centuries, which is why we decided to keep Zeeland apart.

13. See Rutten \& van der Wal (2014:9-10) for the social stratification in the northern Low Countries as suggested by historians. 
Table 2. The Going Dutch Corpus

\begin{tabular}{llrrr}
\hline & & Period 1 & Period 2 & \\
\hline \multirow{2}{*}{ Genre } & & $\mathbf{1 7 7 0 - 1 7 9 0}$ & $\mathbf{1 8 2 0 - 1 8 4 0}$ & Total \\
& Private letters & 105,427 & 105,299 & 210,726 \\
& Diaries and travelogues & 71,157 & 69,350 & 140,507 \\
& Newspapers & 35,323 & 35,322 & 70,645 \\
Region & & 211,907 & $\mathbf{2 0 9 , 9 7 1}$ & $\mathbf{4 2 1 , 8 7 8}$ \\
Centre & North Holland & & & \\
& South Holland & 30,256 & 32,368 & 62,624 \\
& Utrecht & 30,225 & 33,547 & 63,772 \\
Periphery & Friesland & 30,588 & 30,094 & 60,682 \\
& Groningen & 30,757 & 30,949 & 61,706 \\
& North Brabant & 28,875 & 30,323 & 59,198 \\
Other & Zeeland & 30,647 & 25,998 & 56,645 \\
& & 30,559 & 26,692 & 57,251 \\
Gender & Male & 211,907 & 209,971 & 421,878 \\
& Female & 127,112 & 105,657 & 232,769 \\
& & 49,472 & 68,992 & 118,464 \\
& & 176,584 & 174,649 & 351,233 \\
\hline
\end{tabular}

\section{Results}

In this section, we present the results of our case study on Dutch neuter relative pronouns in subject and object position. First, we provide a diachronic overview of late eighteenth- and early nineteenth-century usage (5.1). Then, we discuss the definiteness of the antecedent in relation to Weiland's (1805) prescriptions (5.2), geographical variation (5.3) and gender variation (5.4). Section 5.5 zooms in on genre.

\subsection{Diachronic overview}

Our general results give evidence of a high degree of variation in terms of frequently occurring neuter relative pronouns (Table 3 ). In the entire corpus, the two most frequent variants are hetwelk (32.5\%) and the $d$-form dat (30.8\%), whereas hetgeen (17.5\%) and the $w$-form wat (15.6\%) are somewhat less frequent in both diachronic cross-sections. The fifth variant, viz. welk, turns out to be a comparatively marginal form. 
Andreas Krogull, Rutten Gijsbert \& Marijke van der Wal

Table 3. Distribution of Dutch neuter relative pronouns across time

\begin{tabular}{|c|c|c|c|c|c|c|c|c|c|c|c|c|}
\hline & \multicolumn{2}{|c|}{ dat } & \multicolumn{2}{|c|}{ wat } & \multicolumn{2}{|c|}{ hetgeen } & \multicolumn{2}{|c|}{ welk } & \multicolumn{2}{|c|}{ hetwelk } & \multicolumn{2}{|c|}{ Total } \\
\hline & $\mathrm{N}$ & $\%$ & $\mathrm{~N}$ & $\%$ & $\mathbf{N}$ & $\%$ & $\mathrm{~N}$ & $\%$ & $\mathbf{N}$ & $\%$ & $\mathrm{~N}$ & $\%$ \\
\hline $\begin{array}{l}\text { Period } 1 \\
1770-1790\end{array}$ & 177 & 32.9 & 77 & 14.3 & 102 & 19.0 & 22 & 4.1 & 160 & 29.7 & 538 & 100 \\
\hline $\begin{array}{l}\text { Period } 2 \\
1820-1840\end{array}$ & 134 & 28.5 & 80 & 17.0 & 75 & 15.9 & 14 & 3.0 & 168 & 35.7 & 471 & 100 \\
\hline Total & 311 & 30.8 & 157 & 15.6 & 177 & 17.5 & 36 & 3.6 & 328 & 32.5 & 1,009 & 100 \\
\hline
\end{tabular}

Diachronically, our results indicate a remarkably stable distribution of variants across periods. We do recognise some tendencies with regard to the most frequently used variants, though. In our late-eighteenth-century data, the $d$-form dat (32.9\%) is slightly more frequent than hetwelk (29.7\%), while the latter becomes the prevalent variant in the early nineteenth century (35.7\%), outnumbering dat (28.5\%). Further developments are less notable. The relative frequency of the $w$-form wat only slightly increases from $14.3 \%$ to $17.0 \%$. The additional pronominal forms hetgeen and welk, on the other hand, lose ground in period 2.

In sum, dat and hetwelk prove to be the two predominant neuter relative pronouns in late-eighteenth- and early-nineteenth-century language use. Our corpus data do not show evidence of the rise of the $w$-form wat. As outlined in Section 3.4, Weiland (1805) explicitly rejected the use of wat in certain contexts, depending on the definiteness of the antecedent. This is the topic of 5.2.

\subsection{Definiteness of the antecedent}

In Section 3.3, we pointed out that the definiteness of the antecedent has been regarded as a crucial internal factor affecting variation and change in the Dutch relativisation system. It has been argued, mainly by van der Horst (1988), that $w$-forms entered the language from indefinite to definite contexts; see the cline (7), which we repeat here.

(6) (I) free relatives $>$ (II) clause or sentence $>$ (III) indefinite pronoun $>$ (IV) nominalised adjectives $>(\mathrm{V})$ indefinite noun phrase $>(\mathrm{VI})$ definite noun phrase

Context III comprises a fairly heterogeneous group of indefinite pronouns, including also the idiomatic combination of al(les) wat 'all that' (Schoonenboom 2000:35-46; Rutten 2010:9-10). Hence, we propose a split of context III into IIIa (alles) and IIIb (iets 'something, niets 'nothing', veel 'much, many', weinig 'few').

This part of our case study has two aims. First, we will test the generalisation in (7) on corpus data. Secondly, we will compare our results with Weiland's 
prescriptions. The preferred forms per context in Weiland (1805) are as follows: I: wat; II: dat, hetwelk; IIIa: wat; (IIIb: no indications); IV: preferably dat, hetwelk, welk (wat may occur in usage); V/VI: dat, hetwelk, welk (see also Section 3.4).

In general, the results presented in Figures $2 \mathrm{a}$ and $2 \mathrm{~b}$ certainly show similarities between the most frequently occurring variants per context and the variants preferred by Weiland (1805). However, both late eighteenth- and early nineteenth-century language practice reveal much more variation than Weiland acknowledged.

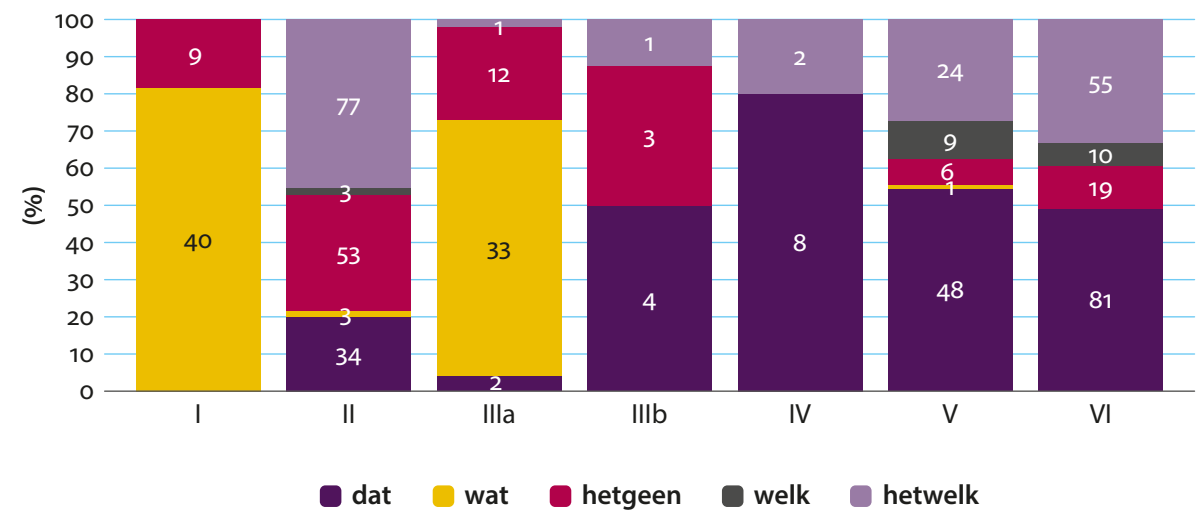

Figure 2a. Distribution of Dutch neuter relative pronouns across context in period 1 (1770-1790)

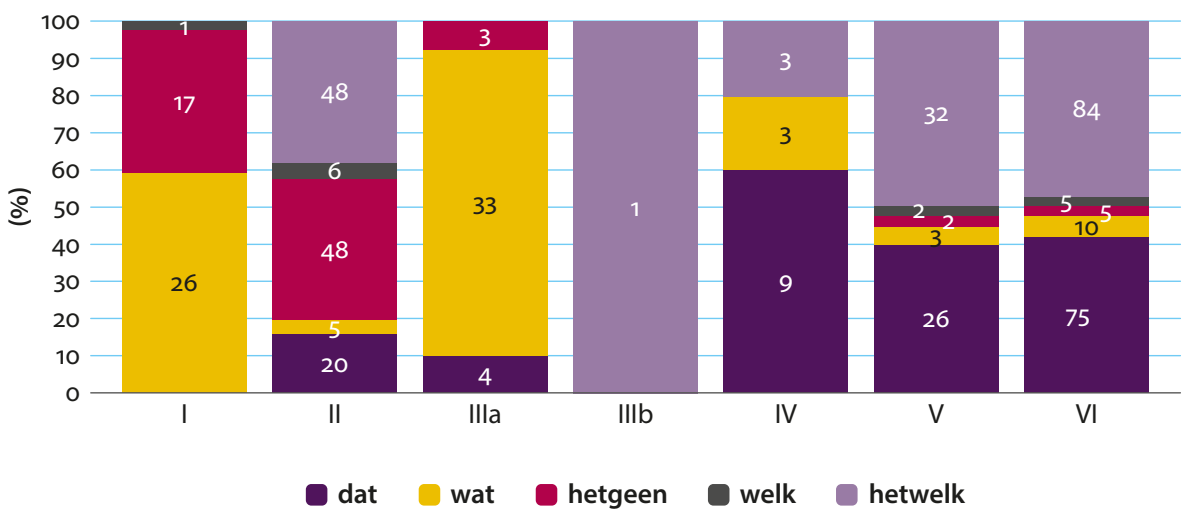

Figure 2b. Distribution of Dutch neuter relative pronouns across context in period 2 (1820-1840)

In both periods, the $w$-form wat turns out to be the most frequently used free relative (context I), occurring in $81.6 \%$ in the late eighteenth century and in $59.1 \%$ in the early nineteenth century. This largely corresponds to Weiland's (1805) preference for wat as a free relative. In our data, however, the alternative relative 
pronoun hetgeen also occurs in $18.4 \%$ in period 1 and even increases to $38.6 \%$ in period 2. As pointed out earlier, we cannot find Weiland's stance on hetgeen in his 1805 grammar, although he did acknowledge it as a legitimate variant in usage in Weiland (1799: 124). The $d$-form dat, on the other hand, is completely absent in context I, where it had been replaced by the $w$-form by that time.

In the case of a sentence or clause as antecedent (context II), the main variants in both periods are hetwelk and hetgeen, although dat also occurs to a lesser extent. In period 2, hetwelk and hetgeen have an equally high share of $37.8 \%$, outnumbering dat (15.8\%). Weiland (1805) suggested the use of dat and hetwelk in these cases, but not the $w$-form wat, which is a minor variant in our results. Moreover, the surprisingly high share of hetgeen in context II contradicts the eighteenthcentury normative tradition, according to which hetgeen is only acknowledged as a free relative (I).

The combination with the indefinite pronoun al(les) (context IIIa) typically appears with wat, apart from a few attestations with hetgeen or dat. Particularly in period 2, wat consolidates its dominant position in this context, increasing from $68.8 \%$ to $82.5 \%$. Weiland (1805) also illustrated this context by two examples with alles wat. Unfortunately, there are too few tokens for context IIIb, but what our tentative results indicate is that the antecedents iets, niets, veel and weinig do not occur with the $w$-form wat, but with either dat, hetgeen or hetwelk - in contrast to al(les). This supports our decision to split context III on the definiteness cline into two sub-contexts.

Similarly, the limited number of tokens for context IV (nominalised adjectives) does not allow for a detailed evaluation. What we can see, though, is that dat occurs in most instances $(80.0 \%$ in period $1 ; 60.0 \%$ in period 2$)$, with some additional attestations of hetwelk and wat. Despite the limited number of tokens, it is notable that the distribution of variants in this context is rather stable.

In many respects, the corpus-based results for contexts $\mathrm{V}$ (indefinite noun phrases) and VI (definite noun phrases) are similar. In period 1, dat is the main variant with a relative frequency of $54.6 \%(\mathrm{~V})$ and $49.1 \%$ (VI), respectively. In both cases, hetwelk turns out to be the second most frequent variant in usage: $27.3 \%$ (V) and 33.3\% (VI). Except for one single attestation of wat, the $w$-form does not occur in our eighteenth-century data. In the nineteenth-century data, we can witness a change in the distribution of variants in these two contexts: dat drops from $54.6 \%$ to $40.0 \%(\mathrm{~V})$ and from 49.1 to $41.9 \%$ (VI). In contrast, the use of hetwelk increases from $27.3 \%$ to $49.2 \%$ in context $\mathrm{V}$ and from $33.3 \%$ to $46.9 \%$ in context VI. There are a few more nineteenth-century attestations of relative wat referring to indefinite and definite noun phrases than in the eighteenth century, but they are still relatively marginal. Weiland (1805) explicitly rejected the use of wat in contexts V/VI, only allowing for dat, hetwelk and welk as 'legitimate' options. 
Although the $w$-form does not gain ground in early nineteenth-century usage, our data indicate that wat occurs in more contexts other than contexts I (free relatives) and III(a) (grammaticalised al(les) wat) - in both periods. In general, the distribution of variants in most contexts is stable across time, except for the increase of hetwelk in contexts V/VI in period 2.

Our results do not give evidence that $w$-relativisers enter the language from the most indefinite to the most definite context. Relative wat does occur in contexts I and IIIa, but not in II, which disproves the assumption of a linear spread on the definiteness cline from left to right. Furthermore, the $w$-form seems to appear, at least as a marginal variant, in contexts IV, V and VI in our nineteenth-century data. This suggests that wat spread to these contexts simultaneously rather than successively.

With respect to the diachronic stability across contexts, we will leave this internal factor out of consideration in the corpus-based analyses of the external variables, i.e. geographical variation (5.3), gender variation (5.4) and genre variation (5.5).

\subsection{Geographical variation}

Figure 3 presents the relative distribution of Dutch neuter relative pronouns across the following seven regions: Friesland (FR), Groningen (GR), North Brabant (NB), North Holland (NH), South Holland (SH), Utrecht (UT) and Zeeland (ZE). See Figure 1 in Section 4 for a map.

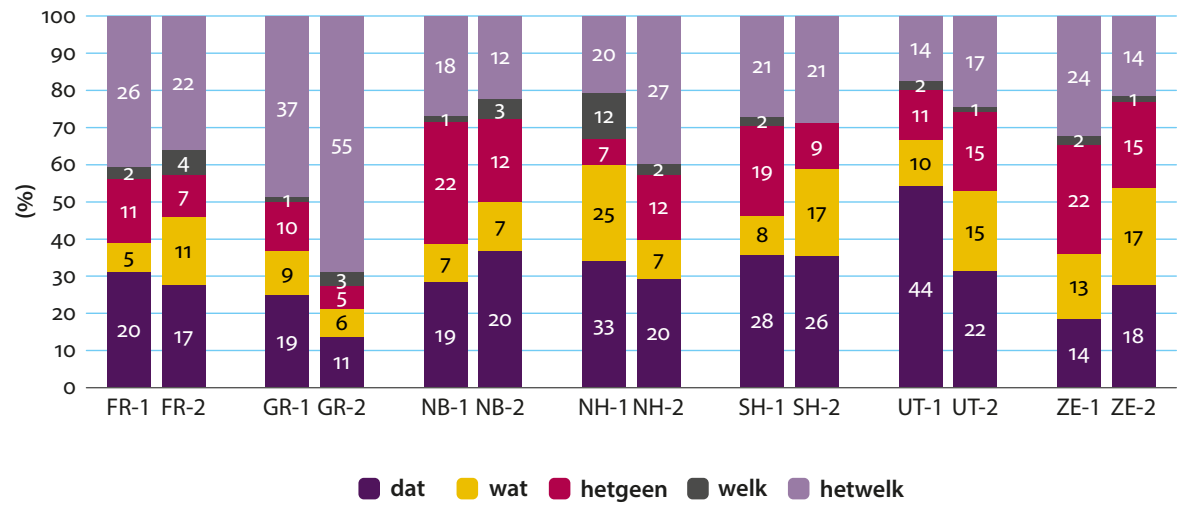

Figure 3. Distribution of Dutch neuter relative pronouns across region and time $(1=$ period 1 , 1770-1790; 2 = period 2, 1820-1840)

In the late eighteenth century, dat occurs by far most frequently in the region of Utrecht (54.3\%), but is also common in South Holland (35.9\%) and North Holland (34.0\%). It is least frequent in Zeeland (18.7\%). In the two northern regions of 
Groningen and Friesland, hetwelk is the dominant variant in late-eighteenth-century usage with a share of $48.7 \%$ and $40.6 \%$, respectively. The other alternative form hetgeen is the prevalent variant in North Brabant (32.8\%) and also among the most frequent variants in Zeeland (29.3\%), both of which are the southernmost regions of the investigated language area. This possibly suggests a north-south difference with regard to the choice of alternative relative pronouns, viz. predominant hetwelk in the north versus relatively high-frequent hetgeen alongside hetwelk in the south.

In the early nineteenth century, the high share of dat in Utrecht decreases from $54.3 \%$ to $31.4 \%$. It also drops in Groningen (from $25.0 \%$ to $13.8 \%$ ), whereas it remains rather stable in Friesland, North Holland and South Holland. In North Brabant and Zeeland, dat slightly gains ground in period 2. The $w$-form wat increases in some regions, particularly in South Holland (from 10.3\% to 23.3\%), Utrecht (from $12.4 \%$ to $21.4 \%$ ) and Zeeland (from 17.3\% to $26.2 \%$ ). More generally, we can attest a diachronic stability in many regions, most notably in Friesland and South Holland, but also in North Brabant and Zeeland.

When we look at the alternative forms hetwelk and hetgeen, the suggested north-south difference is still visible in the nineteenth-century data. Particularly in the region of Groningen, the use of hetwelk increases considerably from 48.7 to $68.8 \%$, consolidating its position as the predominant neuter relative pronoun. In Friesland, the preference for hetwelk (36.1\%) over hetgeen (11.5\%) remains remarkable, too. In the southern regions of Zeeland and North Brabant, on the other hand, hetgeen continues to be a comparatively strong variant in usage with $23.1 \%$ and $22.2 \%$, respectively.

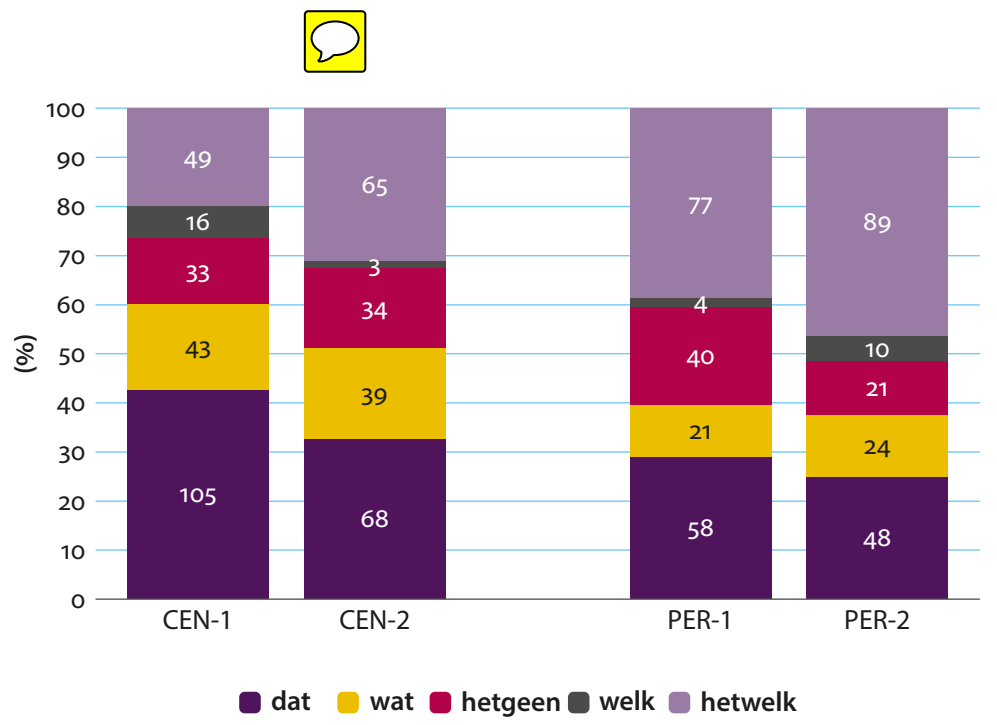

Figure 4. Distribution of Dutch neuter relative pronouns across centre-periphery and time $(1=$ period $1,1770-1790 ; 2=$ period $2,1820-1840)$ 
The distribution of neuter relative pronouns across the second geographical dimension, viz. variation across the centre (CEN; covering North Holland, South Holland, Utrecht) and the periphery (PER; covering North Brabant, Friesland, Groningen), is presented in Figure 4.

In the late eighteenth century, the prevalent variant used in the centre is the $d$-form dat (41.0\%). The remaining variants are considerably less frequent: hetwelk $(21.5 \%)$, wat (16.8\%), hetgeen (13.6\%) and welk (6.3\%). In the periphery, however, hetwelk is the main variant in usage $(39.1 \%)$, outnumbering dat $(28.0 \%)$, hetgeen (20.7\%) and the comparatively low-frequent $w$-form wat $(10.1 \%)$.

In the early nineteenth century, the prevalence of dat diminishes in the centre (from $41.0 \%$ to $32.2 \%$ ), whereas hetwelk gains ground and becomes an almost equally frequent second variant in usage $(30.8 \%)$. The use of wat increases from $10.1 \%$ to $18.5 \%$. In the periphery, the share of hetwelk grows even further, increasing from an already strong $39.1 \%$ to $45.6 \%$. At the same time, dat slightly decreases from $28.0 \%$ to $24.6 \%$.

In sum, the general tendencies, i.e. less dat, more hetwelk, are similar in both the centre and the periphery. However, the prevalence and increase of hetwelk turns out to be more pronounced in the periphery, which may be largely due to the frequent use of this variant in the two northern regions of Friesland and Groningen. In contrast, the distribution of variants in the centre is rather balanced.

\subsection{Gender variation}

Figure 5 reveals remarkable differences in the use of neuter relative pronouns between male $(\mathrm{M})$ and female $(\mathrm{F})$ writers.

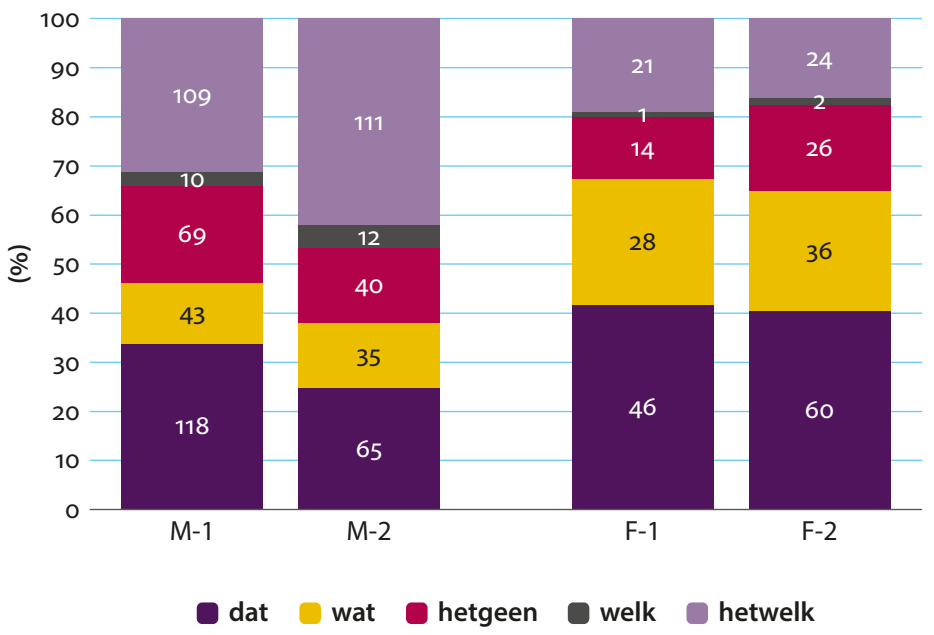

Figure 5. Distribution of Dutch neuter relative pronouns across gender and time $(1=$ period $1,1770-1790 ; 2=$ period $2,1820-1840)$ 
In period 1 , the most frequently occurring variants among male writers are dat (33.8\%) and hetwelk (31.2\%). In the ego-documents produced by their female contemporaries, the prevalence of dat as the main variant is considerably stronger (41.8\%), whereas hetwelk occurs in only $19.1 \%$. The use of the $w$-form turns out to be another gender difference in period 1. In fact, wat is only the fourth most frequent variant used by men (12.3\%), but the second most frequent variant used by women $(25.5 \%)$.

The gender differences increase further in the nineteenth-century period. The distribution of variants in the texts written by women remains extremely stable in period 2. The $d$-/w-forms dat and wat only minimally decrease from $41.8 \%$ to $40.5 \%$ and $25.5 \%$ to $24.3 \%$, respectively. In the texts written by men, however, the developments are more visible. The relative frequency of hetwelk increases from $31.2 \%$ to $42.2 \%$ and takes the position as the main variant in usage at the cost of dat, which drops from $33.8 \%$ to $24.7 \%$. Interestingly, the (varying) shares of wat do not change considerably in male and female texts.

\subsection{Zooming in on genre}

Figure 6 presents the distribution of Dutch neuter relative pronouns across the three genres in the Going Dutch Corpus: private letters (LET), diaries and travelogues (DIA), and newspapers (NEW).

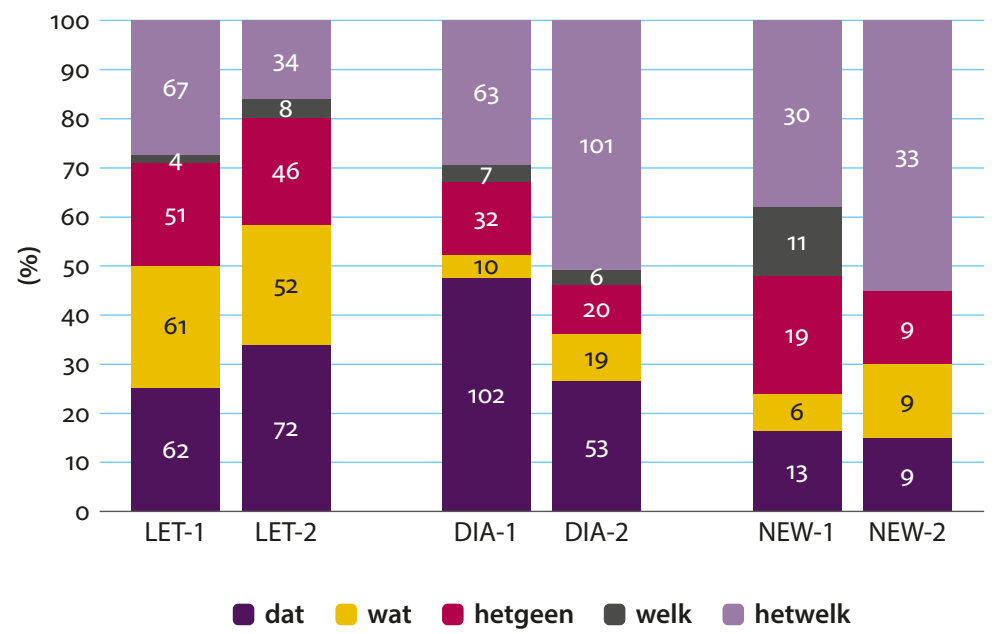

Figure 6. Distribution of Dutch neuter relative pronouns across genre and time $(1=$ period 1 , $1770-1790 ; 2=$ period $2,1820-1840$ )

The results for period 1 reveal notable genre differences. In the private letters, no fewer than four similarly frequent variants are used: both the $d$-/w-forms 
dat $(25.3 \%)$ and wat $(24.9 \%)$ as well as the additional pronominal forms hetwelk (27.4\%) and, to a slightly lesser extent, hetgeen (20.8\%) occur in more than twenty per cent each. In contrast, diaries and travelogues from the first period clearly have a prevalent variant. The $d$-form dat occurs in almost half of all instances (47.7\%), whereas the $w$-form wat is used in only $4.7 \%$. The alternative hetwelk, however, also has a rather high share of $29.4 \%$ in this genre.

The newspaper genre shows yet another distribution of variants in the late eighteenth century. In these printed and published texts, two of the additional forms, viz. hetwelk and hetgeen, are the predominant variants, occurring in 38.0\% and $24.1 \%$, respectively. They both outnumber dat (16.5\%) and particularly wat (7.6\%) Interestingly, the older alternative form welk, which is a marginal variant in both types of ego-documents, has the highest share in newspapers (13.9\%). Furthermore, the comparison of the three genres suggests that the use of wat in period 1 is restricted to private letters, whereas it rarely occurs in diary and newspaper texts.

The distribution of variants in the private letters seems to evolve from a range of similarly frequent variants in period 1 towards one slightly more dominant variant in period 2. In fact, the $d$-form dat increases from $25.3 \%$ to $34.0 \%$. At the same time, the use of hetwelk drops from $27.4 \%$ to $16.0 \%$, whereas wat $(24.5 \%)$ and hetgeen $(21.7 \%)$ generally remain stable.

The developments in the diaries and travelogues are in sharp contrast to those in the private letters. The use of dat considerably decreases from $47.7 \%$ to $26.6 \%$, whereas hetwelk gains ground in period 2 and even becomes the main variant in this genre with $50.8 \%$. A similar development in the use of hetwelk can also be attested for early nineteenth-century newspapers, where this variant further consolidates its dominance, increasing from $38.0 \%$ to $55.0 \%$. With regard to the $w$-form, wat remains a comparatively low-frequency variant in diaries and travelogues $(9.6 \%)$ as well as in newspapers (15.0\%), although its share increases in both genres.

This means that diaries and travelogues develop towards a distribution similar to newspapers in period 2. In order to trace the rise of hetwelk in the diaries and travelogues on a more detailed level, Table 4 shows the distribution of variants across gender in this genre. Although we have to take into account the overrepresentation of male writers ( 40 texts by 40 individuals) and thus a less representative number of female writers (10 texts by 10 individuals), the results indicate interesting tendencies.

In the eighteenth-century data (period 1), male diarists prefer dat (41.6\%) and hetwelk (34.1\%). In the texts written by female diarists, on the other hand, dat $(86.2 \%)$ is predominant, whereas hetgeen and wat are rare, and welk and hetwelk even absent. In the nineteenth century, male writers increasingly use hetwelk (from 
Table 4. Diaries and travelogues: Distribution of Dutch neuter relative pronouns across gender and time $(1=$ period $1,1770-1790 ; 2=$ period $2,1820-1840)$

\begin{tabular}{|c|c|c|c|c|c|c|c|c|c|c|c|c|}
\hline & \multicolumn{2}{|c|}{ dat } & \multicolumn{2}{|c|}{ wat } & \multicolumn{2}{|c|}{ hetgeen } & \multicolumn{2}{|c|}{ welk } & \multicolumn{2}{|c|}{ hetwelk } & \multicolumn{2}{|c|}{ Total } \\
\hline & $\mathrm{N}$ & $\%$ & $\mathbf{N}$ & $\%$ & $\mathrm{~N}$ & $\%$ & $\mathrm{~N}$ & $\%$ & $\mathrm{~N}$ & $\%$ & $\mathrm{~N}$ & $\%$ \\
\hline Male-1 & 77 & 41.6 & 9 & 4.9 & 29 & 15.7 & 7 & 3.8 & 63 & 34.1 & 185 & 100 \\
\hline Male-2 & 35 & 22.0 & 12 & 7.6 & 17 & 10.7 & 6 & 3.8 & 89 & 56.0 & 159 & 100 \\
\hline Female-1 & 25 & 86.2 & 1 & 3.5 & 3 & 10.3 & 0 & 0.0 & 0 & 0.0 & 29 & 100 \\
\hline Female-2 & 18 & 45.0 & 7 & 17.5 & 3 & 7.5 & 0 & 0.0 & 12 & 30.0 & 40 & 100 \\
\hline
\end{tabular}

$34.1 \%$ to $56.0 \%$ ), at the cost of $d a t$ (from $41.6 \%$ to $22.0 \%$ ). The $d$-form dat may remain the main variant used by female writers (45.0\%), but the rise of hetwelk can also be attested here, increasing from no attestations in period 1 to $30.0 \%$ in period 2. However, it seems that particularly men were establishing hetwelk as the main variant in nineteenth-century diaries and travelogues.

\section{Discussion and conclusions}

The many patterns of variation and change in relativisation strategies in various Germanic languages have attracted quite some historical-sociolinguistic attention. In this paper, we have contributed to the ongoing research on relativisation in Dutch by exploring the use of the neuter relative pronoun in subject and object position in eighteenth- and nineteenth-century Dutch. One of the major developments in some West Germanic languages appears to be the change from originally demonstrative $d$-relativisers to originally interrogative $w$-relativisers. The present case exemplifies this change by replacing wat for dat. In the period under investigation, however, the change appears to be incipient still in many contexts. Whereas $w$-forms were on the rise or even dominant in the case of relative adverbs and relative pronominal adverbs (daar $>$ waar, daarin $>$ waarin), the proportion of wat is relatively low in most contexts investigated here. Apart from the fact that it may simply be a more recent change, another important factor may be the presence of many more competing forms. While alwaar 'where' is a more formal alternative that developed alongside waar and daar (Rutten 2010), the set of variants for the neuter pronoun position encompasses five options. In addition to dat and wat, the forms welk, hetwelk and hetgeen exist, which moreover already date back to the sixteenth century or even further back in time. Nonetheless, welk and the extended option hetwelk are based on the interrogative form welk 'which', so even if the change from $d$ - to $w$-forms is not as advanced as in the case of the adverbs, there is still a marked competition from originally interrogative forms. 
One aim of this study was to test the proposed cline of definiteness (6) on historical corpus data, and to see whether wat enters the language from indefinite to definite contexts. It is clear that the various types of antecedent are helpful to the extent that there are two contexts where wat is the dominant form. One of these is the category of free relatives (I), and the other one is what we called IIIa, i.e. a subcategory of III comprising the combination alles wat 'all that'. This means that there is no simple left-to-right movement. Moreover, wat is a marginal form in almost all other categories at the same time, again suggesting that the change does not follow the cline. It will be worthwhile to investigate the distribution of $w$-forms in more recent periods, and to see whether the subsequent spread of wat does happen in accordance with the definiteness of the antecedent. For the period under investigation here, we conclude that this cline is of little relevance for the neuter relative pronoun. The irrelevance of the type of antecedent as an internal factor has also been argued by Romaine (2009: 143-144) with respect to Middle Scots. What is in our case most remarkable about the suggested internal conditioning is the diachronic stability of the results.

As wat is the majority variant in our category IIIa, we would have expected a similar pattern in category II, which includes relativisers with a clause or sentence as antecedent. Likewise, research on the change from $d$ - to $w$-relativisers in the case of adverbs and pronominal adverbs claims that continuative appositives promoted the rise of $w$-forms. This is not confirmed by our results. What we do see is that the $d$-form dat is less frequent in context II, as in I and IIIa, when compared with contexts IV-VI. It is, however, replaced not only by wat, but also by hetgeen and hetwelk, in particular in context II. Our earlier claims that so-called construction grammatical constraints may have more explanatory power is tentatively confirmed. Free relatives (I) constitute a very specific syntactic pattern, as does the fixed combination al(les) wat. Future research will need to show whether certain constructions rather than the definiteness of the antecedent condition the variational patterns found.

As already mentioned, diachronic stability is one of the main results of this study, not only with respect to the internal conditioning, but also in terms of region and gender. The general results for period II are very similar to those for period I. The most obvious difference is the increased frequency of hetwelk, largely at the expense of dat. Similarly, the distribution in regions such as Friesland, Groningen, North Brabant and Zeeland is fairly stable through time. One unexpected outcome is the relative prominence of hetwelk in the north, and the relative prominence of hetgeen in southern regions. This is obviously a result that calls for further investigation as it is interesting to see geographical differences in variants that are sometimes considered formal or typical of written language. If confirmed in future research, it would also imply that the rise of 
hetwelk is a change from the periphery to the centre, as suggested by the centreperiphery distribution across time.

The gender distribution is also relatively stable across time, particularly in the case of female writers. Men, on the other hand, show an increase in the use of hetwelk at the expense of dat. The result for gender becomes slightly different, however, when cross-tabulated with genre. In general, genre is without doubt the most important external factor conditioning the variation of neuter relative pronouns, which in itself confirms our choices when compiling the Going Dutch Corpus. Newspapers and diaries show a remarkable increase in the use of hetwelk, and diaries in particular also show a decrease in the use of dat. Interestingly, diaries are more similar to private letters than to newspapers in period 1 , at least with respect to the proportion of hetwelk, while in period 2 diaries align with newspapers. Diachronically, thus, the two types of ego-document diverge. The rise of hetwelk occurs both in diaries written by men and written by women.

Against the background of a diachronically relatively stable distribution of neuter relative pronouns, diaries and newspapers show an increase of hetwelk. Can we relate this to contemporary language norms? Our research into variation and change in Dutch relativisation patterns is embedded in a research project on the discursive nationalisation of the language in the decades around 1800, which resulted in Weiland's (1805) official grammar. A crucial question relates to the effectiveness of the policy, operationalised as the extent to which changes in the language appear to follow prescription. Recall that Weiland (1805) was much more elaborate with respect to relativisation than any of its predecessors.

When we compare the norms for relativisation culled from Weiland (1805) and the preceding tradition of metalinguistic discourse to the usage patterns found in the Going Dutch Corpus, we conclude that the influence of the normative discourse on language use was fairly limited. Weiland rejected $d$-forms for free relatives (context I) and this was also borne out by our results. Eighteenth-century commentators and Weiland (1799) wanted to restrict the use of hetgeen to free relatives. In practice, it occurs in almost every context in both periods. Weiland (1805) proposed a distribution of forms in accordance with antecedent types, for example dat and hetwelk for clauses and sentences as antecedent (context II), wat in combination with al(les) (IIIa), wat, dat and hetwelk with nominalised adjectives (IV), with wat being dispreferred, and so on. In all these cases, actual usage is more variable with almost all variants occurring in almost all contexts. At the same time, there is a considerable similarity between Weiland (1805) and usage patterns, in that often-rejected forms occur only marginally in certain contexts. However, as already mentioned, the distribution across time remains relatively stable, which implies that the overlap with Weiland (1805) can already be found in the late eighteenth century, when influence of Weiland (1805) is ontologically impossible. 
At one point, the influence of Weiland (1805), either direct or indirect, can be assumed. Weiland combined the traditional forms with the register differences already proposed by ten Kate (1723), and assigned forms such as the masculine and feminine variants welke and dewelke to the so-called solemn register, reserving die for the so-called plain style. Extending these observations to the neuter, we note that the 'solemn' form hetwelk increases in newspapers and diaries, reducing the proportion of the 'plain' variant dat. While we cannot prove that this is a direct result of Weiland's (1805) intervention, it does signal a sociolinguistic situation in which hetwelk primarily indexes formality or 'solemnity', or in any case more strongly than other variants such as dat. Both Weiland and the writers in our corpus testify to this situation.

In this respect, the diachronic results for the diaries and travelogues in our corpus are certainly remarkable. The developments in the distribution of Dutch neuter relative pronouns highlight the special position of these sources as a genre on the oral-literate continuum. Although diaries and travelogues are typically categorised and treated as ego-documents like private letters, it has to be kept in mind that we are dealing with distinct subgenres of ego-documents (cf. Elspaß 2012: 162). Moreover, they are usually less 'oral' and more 'standard'-like (Schneider 2013: 66, cf. Rutten 2012a for a Dutch example).

As to the question posed in the title of our paper: the answer is yes. Writers of ego-documents, both men and women, create a divergence of letters and diaries by adopting hetwelk more strongly in just one type of ego-document. It should be noted that the idea of a national language being restricted to certain genres opposes the discourse of a homogeneous national language symbolising the homogenous Dutch nation. In its strongest version, this discourse was extremely hostile to any kind of variation (cf. Rutten 2016b). Note that Weiland himself, in the case of nominal inflection, was also much less tolerant of variation than some of his eighteenth-century predecessors (Rutten 2012b).

In future research on relative pronouns, other positions than the subject and object position will need to be taken into account, especially since it has been argued that $w$-forms may enter the language first via other positions such as genitival constructions, and subsequently spread to more frequently relativised positions such as subjects and objects (Romaine 2009:151-152, cf. van der Wal 2002). In Modern Dutch, for example, the genitive forms wier and wiens 'whose' are used, and have been used for a very long time, while wie instead of die still only occurs sporadically in masculine and feminine subject and object positions. Another issue is the importance of animacy, as this seems to be a relevant factor cross-linguistically.

This study is the first detailed sociolinguistic corpus study of the use of relative pronouns in historical Dutch. We look forward to extending this research to other 
forms such as the masculine and feminine relative pronouns, as well as to other relativisers and also, more generally, to the relationship between morphosyntactic phenomena and language planning initiatives such as Weiland (1805). The interplay of metalanguage and patterns of language use remains a core topic in historical sociolinguistics. The present study suggests that genre and register are crucially intervening factors therein.

\section{Acknowledgements}

We thank the anonymous reviewers for their comments on an earlier version.

\section{References}

Andersson, Erik. 1994. Swedish. In Ekkehard König \& Johan van der Auwera (eds.), The Germanic Languages, 271-312. London \& New York: Routledge.

Anderwald, Lieselotte. 2016. Language between description and prescription. Verbs and verb categories in nineteenth-century grammars of English. Oxford: Oxford University Press. doi:10.1093/acprof:0so/9780190270674.001.0001

ANS = Algemene Nederlandse Spraakkunst, Online edn. http://ans.ruhosting.nl/e-ans/index. html.

Askedal, John Ole. 1994. Norwegian. In Ekkehard König \& Johan van der Auwera (eds.), The Germanic Languages, 219-270. London \& New York: Routledge.

AdA = Atlas zur deutschen Alltagssprache. By Stephan Elspaß \& Robert Möller. http://www.atlasalltagssprache.de/

Barnes, Michael P. \& Eivind Weyhe. 1994. Faroese. In Ekkehard König \& Johan van der Auwera (eds.), The Germanic Languages, 190-218. London \& New York: Routledge.

Bergs, Alexander. 2005. Social networks and historical sociolinguistics: Studies in morphosyntactic variation in the Paston letters (1421-1503). Berlin: Mouton de Gruyter. doi: $10.1515 / 9783110923223$

Bolhuis, Lambertus van. 1792. Beknopte Nederduitsche spraakkunst. Leiden, Deventer \& Groningen: du Mortier, de Lange \& Oomkens.

Braune, Wilhelm. 1981. Gotische Grammatik mit Lesestücken und Wörterverzeichnis. Ed. Ernst A. Ebbinghaus. Tübingen: Max Niemeyer.

Elspaß, Stephan. 2005. Sprachgeschichte von unten. Untersuchungen zum geschriebenen Alltagsdeutsch im 19. Jahrhundert. Tübingen: Niemeyer. doi:10.1515/9783110910568

Elspaß, Stephan. 2012. The use of private letters and diaries in sociolinguistic investigation. In Juan Manuel Hernández-Campoy \& Juan Camilo Conde-Silvestre (eds.), The handbook of historical sociolinguistics, 156-169. Chicester: Wiley-Blackwell. doi:10.1002/9781118257227.ch9

Elzevier, Kornelis. 1761. Drie dichtproeven [...] benevens een proef van een nieuwe Nederduitsche spraekkonst. Haarlem: Bosch.

Fischer, Olga. 1992. Syntax. In Norman Blake (ed.), The Cambridge History of the English Language. Volume II. 1066-1476, 207-408. Cambridge: Cambridge University Press. 
Haberland, Hartmut. 1994. Danish. In Ekkehard König \& Johan van der Auwera (eds.), The Germanic Languages, 313-348. London \& New York: Routledge.

Haes, Frans de. 1764. De nagelaten gedichten, en Nederduitsche spraekkunst. Amsterdam: Meijer. Hinrichs, Lars, Benedikt Szmrecsanyi \& Axel Bohmann. 2015. Which-hunting and the Standard English relative clause. Language 91. 806-836. doi:10.1353/lan.2015.0062

Horst, J. M. van der. 1988. Over relatief dat en wat. De nieuwe taalgids 81. 194-205.

Horst, J. M. van der. 2008. Geschiedenis van de Nederlandse syntaxis, 2 vols. Louvain: Leuven University Press.

Horst, J. M. van der \& R. Storm. 1991. Over de geschiedenis van het betrekkelijk voornaamwoordelijk bijwoord. Tijdschrift voor Nederlandse Taal- en Letterkunde 107. 105-119.

Huydecoper, Balthazar. 1730. Proeve van taal- en dichtkunde. Amsterdam: Visscher \& Tirion.

Kate, Lambert ten. 1723. Aenleiding tot de kennisse van het verhevene deel der Nederduitsche sprake. Amsterdam: Wetstein.

Kloek, Joost \& Wijnand Mijnhardt. 2004. 1800. Blueprints for a national community. Assen: Royal Van Gorcum and Palgrave Macmillan.

Kunst wordt door Arbeid verkreegen. 1770. Nederduitsche spraekkunst. Leiden: Hoogeveen.

Langer, Nils. 2011. Historical sociolinguistics in nineteenth-century Schleswig-Holstein. German Life and Letters 64. 169-178. doi:10.1111/j.1468-0483.2010.01528.x

Lindeman, Ruud, Yvonne Scherf \& Rudolf Dekker. 1994. Reisverslagen van Noord-Nederlanders van de zestiende tot begin negentiende eeuw: een chronologische lijst. Rotterdam: Erasmus Universiteit.

Moonen, Arnold. 1706. Nederduytsche spraekkunst. Amsterdam: Halma.

Negele, Michaela. 2012. Varianten der Pronominaladverbien im Neuhochdeutschen. Grammatische und soziolinguistische Untersuchungen. Berlin: De Gruyter. doi: 10.1515/9783110273281

Nevalainen, Terttu \& Helena Raumolin-Brunberg. 2003. Historical sociolinguistics: Language change in Tudor and Stuart England. London: Longman.

Nevalainen, Terttu \& Helena Raumolin-Brunberg. 2012. Historical sociolinguistics: Origins, motivations, and paradigms. In Juan Manuel Hernández-Campoy \& Juan Camilo CondeSilvestre (eds.), The handbook of historical sociolinguistics, 22-59. Chicester: Wiley-Blackwell. doi:10.1002/9781118257227.ch2

Palm, Kornelis van der. 1769. Nederduitsche spraekkunst voor de jeugdt. Rotterdam: Arrenberg.

Rissanen, Matti. 1999. Syntax. In Roger Lass (ed.), The Cambridge History of the English Language. Volume III. 1476-1776, 187-331. Cambridge: Cambridge University Press.

Romaine. 2009 [1982]. Socio-historical Linguistics: Its status and methodology. Cambridge: Cambridge University Press.

Rudimenta. 1802. Rudimenta of gronden der Nederduitsche spraake, 2nd edn. Leiden, Deventer \& Utrecht: du Mortier, de Lange \& van Paddenburg.

Rutten, Gijsbert. 2010. Vroegmoderne relativa: naar een diachrone constructiegrammatica. Nederlandse taalkunde 15. 1-32. doi:10.5117/NEDTAA2010.1.VROE427

Rutten, Gijsbert. 2012a. From adverb to conjunction and back. The (de)grammaticalization of Dutch dan. Diachronica 29(3). 301-325. doi:10.1075/dia.29.3.02rut

Rutten, Gijsbert. 2012b. "Lowthian" linguistics across the North Sea. Historiographia Linguistica 39. 43-59. doi:10.1075/hl.39.1.04rut

Rutten, Gijsbert. 2016a. The 'Golden Age Myth': The construction of Dutch as a national language. In G. Rutten \& K. Horner (eds.), Metalinguistic perspectives on Germanic languages: European case studies from past to present, 13-34. Oxford: Peter Lang. doi:10.3726/b11384 
Rutten, Gijsbert. 2016b. Standardization and the myth of neutrality in language history. International Journal of the Sociology of Language 242. 25-57.

Rutten, Gijsbert, Rik Vosters \& Wim Vandenbussche (eds.). 2014. Norms and usage in language history, 1600-1900: A sociolinguistic and comparative perspective. Amsterdam: John Benjamins. doi:10.1075/ahs.3

Rutten, Gijsbert \& Marijke J. van der Wal. 2014. Letters as loot: A sociolinguistic approach to seventeenth- and eighteenth-century Dutch. Amsterdam: John Benjamins. doi:10.1075/ahs.2

Rutten, Gijsbert \& Marijke van der Wal. 2017. Discourse continuity and the written medium: Continuative relative clauses in the history of Dutch. In Daniel van Olmen, Hubert Cuyckens \& Lobke Ghesquière (eds.), Aspects of Grammaticalization. (Inter)Subjectification and Directionality, 113-138. Berlin: De Gruyter.

SAND = Syntactische Atlas van de Nederlandse Dialecten. 2005. Vol. 1. By Sjef Barbiers, Hans Bennis, Gunther De Vogelaer, Magda Devos \& Margreet van der Ham. Amsterdam: Amsterdam University Press.

Schneider, Edgar W. 2013. Investigating historical variation and change in written documents. New perspectives. In J. K. Chambers \& Natalie Schilling (eds.), The handbook of language variation and change, 2nd edn., 57-81. Oxford: Blackwell. doi:10.1002/9781118335598.ch3

Schoonenboom, Judith. 1997. De geschiedenis van dat, wat en hetgeen in bijbelvertalingen. Nederlandse Taalkunde 2. 343-369.

Schoonenboom, Judith. 2000. Analyse, norm en gebruik als factoren van taalverandering. Een studie naar veranderingen in het Nederlands onzijdig relativum. Unpublished $\mathrm{PhD}$ dissertation Universiteit van Amsterdam.

de Schutter, Georges \& Hanne Kloots. 2000. Relatieve woorden in het literaire Nederlands van de 17e eeuw. Nederlandse Taalkunde 5. 325-342.

Sewel, Willem. 1708. Nederduytsche spraakkonst. Amsterdam: Lansvelt.

Sewel, Willem. 1712. Nederduytsche spraakkonst, 2nd edn. Amsterdam: Blokland.

Siegenbeek, Matthijs. 1804. Verhandeling over de Nederduitsche spelling ter bevordering van de eenparigheid in dezelve. Amsterdam: Allart.

Stijl, Klaas \& Lambertus van Bolhuis. 1776. Beknopte aanleiding tot de kennis der spelling, spraakdeelen, en zinteekenen van de Nederduitsche taal. Groningen: Oomkens.

Thráinsson, Höskuldur. 1994. Icelandic. In Ekkehard König \& Johan van der Auwera (eds.), The Germanic Languages, 142-189. London \& New York: Routledge.

Tollius, Herman. 1776. Proeve eener Aanleiding tot de Nederduitsche Letterkunst.

Verwer, Adriaen. 1707. Schets van de Nederlandse taal grammatica, poëtica, retorica. Dutch translation of Linguae Belgicae idea grammatica, poetica, rhetorica. Amsterdam: Halma.

Wal, Marijke J. van der. 2002. Relativisation in the history of Dutch: Major shift or lexical change? In P. Poussa (ed.), Relativisation on the North Sea Littoral, 27-35. München: Lincom.

Wal, Marijke J. van der. 2002b. Lambert ten Kate and eighteenth-century Dutch linguistics. Beiträge zur Geschichte der Sprachwissenschaft 12. 49-63.

Wal, Marijke J. van der. 2003. Relativiteit in de grammaticale traditie. Tussen norm en descriptie? In E. Ruijsendaal, G. Rutten \& F. Vonk (eds.), Bonjours Neef, ghoeden dagh Cozyn, 361-375. Münster: Nodus.

Weiland, Petrus. 1799. Nederduitsch taalkundig woordenboek. Amsterdam: Allart.

Weiland, Petrus. 1805. Nederduitsche spraakkunst. Amsterdam: Allart. 